\section{Fatal Endotoxic Shock of Biliary Tract Origin Complicating Transhepatic Cholangiography}

\section{R. B. KEIGHLEY, G. WILSON, J. P. KELLY}

British Medical fournal, 1973, 3, 147-148

A case of proved endotoxic shock from the biliary tract after transhepatic cholangiography is reported. We know of no previous report in the literature.

\section{Case Report}

A 70-year-old man was admitted to hospital with a five-month history of painless jaundice. Previous history included quiescent Pott's disease of the spine, endogenous depression, and Parkinsonism.

Examination showed obvious jaundice and a pronounced lumbar kyphosis. There was no ascites, hepatosplenomegaly, or a palpable abdominal tumour. Haematological investigations were normal. The E.S.R. (Westergren) was $135 \mathrm{~mm} /$ in the first hour. Liver function tests were: total bilirubin $15.0 \mathrm{mg} / 100 \mathrm{ml}(8.5 \mathrm{mg}$ conjugated), alkaline phosphatase 27 K.A. units, SGPT 37 units, prothrombin time 17 seconds (control 12 seconds), serum proteins were normal. There was no evidence of occult gastrointestinal bleeding. Liver biopsy showed changes of extrahepatic obstruction. Hypotonic duodenography and pancreatic arteriography were thought to be normal.

Arrangements were made for percutaneous transhepatic cholangiography to be followed by laparatomy. The lateral approach was used and white bile was aspirated on the second attempted puncture. The extrahepatic biliary tract was shown to be dilated proximal to a stone, which was partially occluding the distal end of the common bile duct (see fig.).

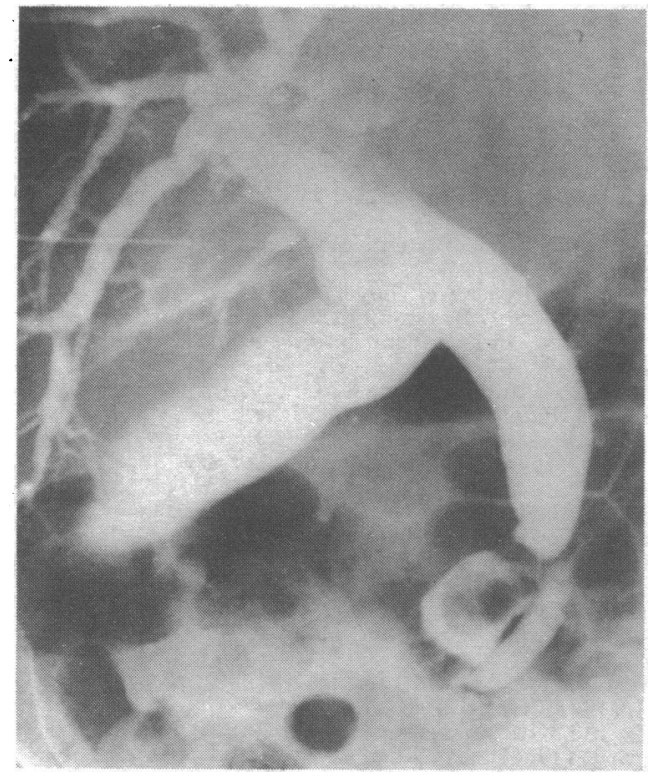

Transhepatic cholangiogram showing a stone at termination of common bile and pancreatic ducts.

One and a half hours after cholangiography the patient developed a rigor and became hypotensive with a warm vasodilated peripheral circulation. His general condition rapidly deteriorated and a

Leeds (St. James's) University Hospitâ!, I.eeds 9

M. R. B. KEIGHLEY, F.R.C.s., Surgical Registrar

G. WILSON, F.R.C.S., Consultant Surgeon

J. P. KELLY, M.B., CH.B., Senior House Officer transient purpuric rash was noted. There was no clinical evidence of biliary peritonitis or intra-abdominal bleeding. A diagnosis of Gram-negative endotoxic shock was made. After blood culture central venous pressure was monitored with an initial recording of $-8 \mathrm{~cm}$ of saline: Treatment consisted of $3 \mathrm{~g}$ hydrocortisone, 300 ml $8.4 \%$ sodium bicarbonate to correct a severe metabolic acidosis (base deficit: $16 \mathrm{mEq} / \mathrm{l}$ ), and four units of plasma. Antibiotic therapy included cephaloridine, cloxacillin, and gentamicin. After resuscitation thewcentral venous pressure returned to normal and the patient rapidly improved. Despite this only small quantities of urine were passed, and a diagnosis of acute tubular necrosis was made.

Within four hours of the onset of hypotension he was taken to theatre and the presence of a stone impacted in the distal end of the common bile duct was confirmed. This was removed piecemeal through a supraduodenal choledochotomy incision. There was no evidence of biliary leakage or haemorrhage from the puncture site in the liver. The common duct was sutured around a T-tube and the abdomen closed.

After an initial eight-hour period of hypotension the blood pressure returned to normal, but the urine output never exceeded $30 \mathrm{ml} / \mathrm{hr}$. The blood urea progressively rose despite digitalization, osmotic loading, and large doses of frusemide. Because of impaired renal function cephaloridine and gentamicin were discontinued and carbenicillin was substituted. On the third postoperative day the patient became anuric and developed signs of hepatic coma. Next day the blood urea had risen to $370 \mathrm{mg} / 100 \mathrm{ml}$, and serum potassium was $7.4 \mathrm{mEq} / 1$. Arrangements were made for haemodialysis after insulin and glucose cover, but the patient died before treatment was begun. Permission for necropsy was not granted.

The microbiological findings in this patient are of great interest. Repeated preoperative blood cultures ( $x \quad \sigma$ ) after cholangiography grew numerous colonies of Eschericia coli. $\boldsymbol{E}$. coli was also isolated from the common bile duct at operation $\left(1 \times 10^{7}\right.$ organisms $\left./ \mathrm{ml}\right)$ and during cholangiography. Duodenal samples and a liver biopsy specimen taken at operation were also colonized by the same pathogen. All postoperative blood cultures were sterile. No pathogens were found in the bile from the T-Tube on the second postoperative day. The bacteria isolated from the blood stream and the biliary tract were studied. B:ochemical reactions confirmed that both of these were $\boldsymbol{E}$. coli. Both colicine susceptibility and serological typing were similar. We believe, therefore, that the onganisms cultured from these sites were identical. For this reason we conclude that the pathogen found in the blood stream after cholangiography was of biliary tract origin and therefore responsible for the development of endotoxic shock. The sensitivity of antibiotics to this organism were as follows: -sensitive-tetracycline, streptomycin, chloramphenicol, cephaloridine, carbenicillin, gentamicin, and the sulphonamides; resistant -ampicillin and rifampicin.

\section{Comment}

There are a number of instances where unexplained hypotension has occurred after transhepatic cholangiography which have been attributed to anaphylaxis or a hypersensitivity reaction to the contrast medium (Prioton, 1960; Santos et al., 1960). Rigors and shivering attacks have also been described (Arner et al., 1962; Seldinger, 1966). Frank septicaemia has also been recorded, but in only one of these cases has the organism been positively identified (Castiglioni and Petronio, 1964; Flemma et al., 1965; Dodd, 1967). Koch and Gardner (1969) described an interesting case where an episode of hypotension associated with chills and pronounced vasoconstriction occurred after percutaneous transhepatic cholangiography. In this instance an antecedent history of cholangitis was noted. These authors attributed this episode to blood stream infection occurring from the biliary tree due to a "blood-bile fistula" created by the cannula at cholangiography.

Septicaemia which has been recorded after transhepatic cholangiography should not be confused with the clinical picture of endotoxic shock. Though the cause of these two conditions may be similar, the pathogenesis, presentation, and prognosis are quite different (Rogers et al., 1965). This is probahlv due to toxins released from the bacterial cell wall (Borden and Hall, 195i). Anart from pathogenesis, the mortality of en- 
dotoxic shock is very much higher than uncomplicated bacteraemia (Murdoch et al., 1968), particularly in the extremes of life (Altemeier et al., 1967), and acute renal failure is a frequent complication (Riorden and Walters, 1968). This syndome has been observed after biliary tract operations (Keighley, 1973) and has recently been recorded after endoscopic retrograde choledochopancreatography (Blumgart et al., 1972). It is not unreasonable to assume, therefore, that this event should be a predictable hazard of this particular investigation.

Percutaneous transhepatic cholangiography is regarded by most people to be a safe and valuable method of investigation (Atkinson et al., 1960; Glenn et al., 1962; Shaldon et al., 1962; George et al., 1965). It is extremely helpful in distinguishing hepatocellular jaundice from extrahepatic obstruction. The nature of any obstruction is usually clearly shown by this technique. Since complications are more frequent in these patients, laparotomy should always be available (Evans et al., 1962; Dodd, 1967; Machado, 1971). These complications include puncture of the gall bladder or common bile duct (DeMasi et al., 1967; James, 1971), penetration of hollow viscera (George et al., 1965), pneumothorax (Turner and Costopoulos, 1968), subphrenic abscess (Thorbjarnarson et al., (1967), and even haemopericardium (James, 1971). By far the biggest hazard, however, is the occurrence of bile leakage (Atkinson et al., 1960; Shaldon et al., 1962) and intraperitoneal bleeding (Machado, 1971). Despite this alarming list the overall incidence of severe complications is generally less than 5\% (Atkinson et al., 1960; Machado, 1971).

Blood stream infection must be regarded as one of the dangers of operative and radiographic procedures undertaken on patients with obstructive jaundice (Dodd, 1967). We know that $70 \%$ of patients in this category have infected bile with bacterial counts well over $1 \times 10^{6}$ organisms $/ \mathrm{ml}$. (Scott, 1971; Keighley, 1973). What is not so often appreciated, however, is that if the obstruction is due to stones, as compared with neoplastic occlusion, biliary infection is almost invariably present (Scott and Khan, 1967; Keighley, 1973). It is not surprising, therefore, to find blood stream infection complicating these procedures. Evidence that this can occur has been shown by a direct anatomical communication from the biliary canaliculi to the liver sinusoides in obstructive jaundice (Hultborn et al., (1962) and by cholangiovenous reflux during cholangiography under these circumstances (Edlund and Hanzon, 1953). A pressure gradient from the intrahepatic biliary radicles to the sinusoides also exists in these cases (Weichel, 1964; Carlson, 1970). We have recently become aware of the importance of blood stream spread from the bile after choledochotomy with T-tube drainage (Keighley and Graham, 1971). Proved bacteraemia has also been found after T-tube cholangiography in four patients with infected bile and impaired biliary drainage (Keighley, 1973).

Having established that blood stream infection may occur after transhepatic cholangiography, means of avoiding this event should be considered. It is conceivable that bacteraemia from biliary organisms might be induced by avoiding the injection of contrast at high pressures. Some authors consider cholangiography to be contraindicated in patients with a history of cholangitis (Dodd, 1967). Two Canadian papers, regarded antibiotic cover as essential practice (Turner and Costopoulos, 1968; Ritchie et al., 1969). There is much doubt, however, as to the adequacy of antibiotic excretion in the bile among patients with obstructive jaundice (Scott, 1971). Because of this there may be a place for the use of local anti- biotics inserted through the cannula in this investigation (Dodd, 1967). Present evidence suggests that the tetracyclines remain the most effective agents as a prophylaxis against bacteria commonly found in the biliary tract in an otherwise healthy patient (Keighley and Graham, 1973). Most organisms are resistant to broad spectrum penicillins and Rifampicin. Many other valuable agents are too toxic to be routinely recommended.

One should always consider the possibility of blood stream infection occuring after direct biliary tract radiology in the presence of calculus obstructive jaundice. Since Gram-negative organisms are commonly implicated, endotoxic shock will remain a real hazard to these patients. We do not think that this should detract from the value of transhepatic cholangiography since this event appears to be uncommon. Early recognition of the syndrome, however, is important for successful supportive therapy to be effective.

We advise the use of routine bile cultures and antibiotic cover in all patients undergoing transhepatic cholangiography to prevent the occurrence of this sinister complication.

We thank Dr. H. Herlinger and Dr. S. Jacobs respectively for their advice on matters concerning the radiology and bacteriological findings. We also wish to thank Mrs. M. Brown for her secretarial help.

\section{References}

Altemeier, W. A., Todd, J. C., and Inge, W. W. (1967). Annals of Surgery, 116, 530 .

Atkinson, M., Happey, M. G., and Smiddy, F. C. (1960). Gut, 1, 357.

Arner, O., Hazberz, S., and Seldinger, S. J. (1962). Surgery, 52, 561.

Blumgart, L. H., et al. (1972). Lancet, 2, 1269.

Borden, C. W., and Hall, W. H. (1951). New England fournal of Medicine, 245,760 .

Carlson, H. C. (1970). Medical Clinics of North America, 54, 875

Castiglioni, G. C., and Petronio, R. (1964). Surgery, 56, 636

DeMasi, C. J., Akdamar, K., Sparks, R. D., and Hunter, F. M. (1967) fournal of the American Medical Association, 201, 225.

Dodd, G. R. (1967). Surgical Clinics of North America, 47, 1095

Edlund, Y. A., and Hanzon, V. (1953). Acta Anatomica, 17, 105.

Evans, J. A., Glenn, F., Thorbjarnarson, B., and Mujahed, Z. (1962). Radiology, 78, 362

Flemma, R. J., Capp, M. P., and Shingleton, W. W. (1965). Archives of Surgery, 90,5

George, P., Young, W. B., and Walker, J. C., and Sherlock S., (1965). British fournal of Surgery, 52, 779

Glenn, F., Evans, J. A., Mujahed, Z., and Thorbjarnarson, B. (1962). Annals of Surgery, 156, 451 .

Hultborn, A., Jacobson, B., and Rosengren, B. (1962). Acta Chirurgica Scandinavica, 123, 111

James, M. (1971). Archives of Surgery, 103, 31

Keighley, M. R. B. (1973). Unpublished observations.

Keighley, M. R. B., and Graham, N. G. (1971). British fournal of Surgery, 56,764 .

Keighley, M. R. B., and Graham, N. G. (1973). Fournal of the Royal College of Surgeons, Edinburgh. To be published.

Koch, R. L., and Gardner, J. L. (1969). Radiology, 93, 67.

Machado, A. L. (1971). British fournal of Surgery, 58,616.

Murdoch, J. McC., Spiers, C. F., and Pullen, H. (1968). British fournal of Hospital Medicine, 1, 346 .

Hospital Medicine, 1, 346.
Prioton, J. B. (1960). Presse Médical, 68, 2308.

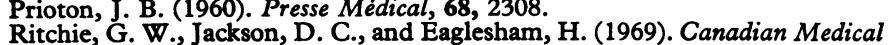
Association fournal, 100, 110 .

Riorden, J. F., and Walters, G. (1968). Lancet, 1, 719.

Rogers, D. E., Koenig, M. G., and Holmes, K. K. (1965). Scottish Medical fournal, 58, 1391.

Santos, M., Figueroa, L., and Lopez, O. (1960). Surgery, 48, 295.

Scott, A. J. (1971). Gut, 12, 487.

Scott, A. J., and Khan, G. A. (1967). Lancet, 2, 790.

Seldinger, S. J. (1966). Acta Radiologica, Suppl. No. 253.

Shaldon, S., Barber, K. M., and Young, W. B. (1962). Gastroenterology, 42, 371 .

Thorbjarnarson, B., Mujahed, Z., and Glenn, F. (1967). Annals of Surgery, $165,33$.

Turner, F. W., and Costopoulos, L. B. (1968). Canadian Medical Association Fournal, 99,513 .

Weichel, K. L. (1964). Acta Chirurgica Scandinavica, Suppl. No. 330. 